Patients and their families often live out of sight and in dreadful conditions, especially in developing nations. Dilias village has limited access to running water.

Despite their own hardship, many have helped research into the condition - with little tangible reward. Most of them are Catholics, so their meeting with Pope Francis is a thank you from the scientists who arranged the event. These researchers are acutely aware of how much they have relied on the patients - the gene that causes Huntington's was discovered thanks to tissue donations from poor Venezuelan families - and that they have not been able to do anything to change their dire situation.

The fact that Pope Francis quickly agreed to meet the families speaks to his hallmark philosophy of reaching out to poor and disadvantaged people. But it is also further evidence of a new openness towards science, which has followed a 2015 encyclical - a letter of guidance on particular themes written by a pope to his bishops - called Laudato si. The encyclical argued for better stewardship of the planet and excited scientists with its forthright pronouncements on the need to control greenhouse gases and with its implicit acceptance of the principles of evolution in well-informed discussion of the need to protect biodiversity. It also acknowledges the value of scientific and academic freedom in society, and the need for open scientific debate on advances in biology.

The Huntington's event is a gesture that shows in a small but significant way in which religious leaders and science can work towards a common goal.

While the Vatican has supported its elite Pontifical Academy of Sciences for more than 80 years, other grass-roots initiatives are emerging. For example, last month Italian researchers collaborated with The Lancet to organize a conference in Rome called (with undeniable hubris) The

Future of Humanity Through the Lens of Medical Science. Attended by Nobel laureates and Vatican officials, its discussions ranged beyond biomedicine to encompass themes such as climate change and migration, mirroring the spectrum of Laudato si.

There is a chasm between religion and science that cannot be bridged. For all its apparent science-friendliness, Laudato si' sticks to the traditional Vatican philosophy that the scientific method cannot deliver the

"There is a chasm between religion and science that cannot be bridged." full truth about the world. However, there is still much to be discussed on how each side can help the other to converge on shared goals.

The Catholic Church has more than 1.2 billion members and can thus have broad influence on the acceptance of facts that some politicians choose to distort - such as the existence of anthropogenic climate change. Scientists can provide technical solutions for poor and sick people, thereby assisting the work of missionaries.

In Rome, Huntington's researchers still desperately seeking a treatment for the disease will have an opportunity to discuss with Pope Francis sensitive issues relating to avoidance of the disease, namely contraception and embryo selection. Francis rarely misses an opportunity to reiterate his view of the sanctity of the human embryo (a theologically debatable Vatican position that has hindered important stem-cell research in some countries) but he seems to keep his views on contraception - outlawed by the Church — deliberately ambiguous. The special audience may help to encourage a much-needed move from the Vatican towards the mercy (and reality - Catholics in rich countries routinely ignore the ban) of finally allowing followers, including those with devastating hereditary disease, to take control of their fertility.

\title{
In a hole
}

\section{The nuclear-waste legacy of the cold war must be addressed.}

$\mathrm{T}$ The United States is still fighting the cold war. Thousands of its citizens had to take shelter last week because of the threat of radiation from nuclear weapons. But the opponent is no longer the Soviet Union. The enemy now is the legacy of an arms race and decades of government indifference to the mess that has been left behind.

On 9 May, the roof collapsed in a tunnel that houses highly radioactive waste at the US Department of Energy's sprawling Hanford site in Washington state. The tunnel is one of a pair that together shield 36 radioactive railway carriages, once used to carry nuclear fuel for reprocessing to plutonium. Radiation monitors showed no signs of airborne contamination after the collapse, so workers at the site were released and the hole was filled with fresh soil.

The incident is yet another alarming reminder of the risks posed by pollution at nuclear-weapons facilities in the United States and around the world. It could have been much worse. And without serious and sustained efforts to clean up these ageing facilities, one day it will be.

In August 2015, an independent panel of academics placed the Hanford tunnels on a list of high-priority dangers at the site, which spreads for more than 1,500 square kilometres along the Columbia River. The interim report, by the Consortium for Risk Evaluation with Stakeholder Participation (CRESP), said that the oldest tunnel — built in 1956 and covered with soil nearly 2.5 metres deep - could collapse and release radiation during an earthquake. The energy department is still investigating last week's breach, but the 6-metre section that gave way may have succumbed to little more than old age.

The energy department has spent more than US $\$ 164$ billion cleaning up its nuclear-waste sites since 1989. But it will be many decades before the work is complete. Each year, the agency spends more money just to maintain old infrastructure and ensure workers are safe.

Science might yet offer more efficient and economic solutions. Whereas Congress and previous administrations have been willing to spend money to maintain — or upgrade - the nuclear weapons themselves, there is less interest in paying to clean up after them. US President Donald Trump is no different. His administration's initial 2018 budget outline would boost funding for the environmental clean-up of nuclear waste by around $\$ 300$ million, to $\$ 6.5$ billion. But the National Nuclear Security Administration, which runs the energy department's weapons programme, would fare better with an increase of $\$ 1.4$ billion, or $11 \%$.

Money is not the only problem. For more than a decade, organizations such as the US National Academies of Sciences, Engineering, and Medicine have been raising questions about the regulatory challenges that impede clean-up. For instance, the energy department's nuclear waste is still classified by where it comes from, rather than by its actual radiological risk. This often increases clean-up costs, and so heightens danger in a budget-constrained world. Nor is the department able to focus its resources on the highest priorities, given myriad legal agreements with state and federal regulators at individual sites - Hanford included.

In a second report in August 2015, CRESP said that the extent to which the clean-up programme is based on actual risk remains "unclear". The report recommended that Congress establish an interagency task force, with the participation of independent experts, to advise the department on clean-up activities and to help navigate legal and regulatory issues. Controversially, CRESP also recommended the creation of an alternative dispute-resolution process to replace the court-approved agreements that govern individual sites.

Objections to that report were raised by the governor and attorney general of Washington state, which has one such agreement at Hanford. This is testimony to the complexity of the problem. Still, the energy department would benefit from a broader reassessment of its clean-up mission - and a regular injection of unbiased risk analysis. The carriages in the Hanford tunnels are not going anywhere soon. But it should be science that dictates their timetable. 